\title{
The History of Research in Vestibular Organ and Benign Paroxysmal Positional Vertigo
}

\author{
Kee Hyun Park \\ Park Kee Hyun Otolaryngology Clinic, Busan, Korea \\ 전정기관과 양성발작성두위현기 연구 역사 \\ 박기현 \\ 박기현 이비인후과의원
}

Received March 16, 2021

Revised June 7,2021

Accepted June 7, 2021

Address for correspondence

Kee Hyun Park, MD

Park Kee Hyun

Otolaryngology Clinic,

1392 Nakdongnam-ro, Saha-gu,

Busan 49426, Korea

Tel $+82-51-205-8988$

Fax $+82-51-205-8930$

E-mail pkent@hanmail.net
Since B.C., vertigo had been described as a condition closely related to migraines or epilepsy. This perception remained during the 14 th -16 th century and vertigo was considered to be a symptom of brain disease. Until the 18th century, the perception remained that the vestibular organ would be in charge of hearing. However, during the 19th century, it was understood that the sense of equilibrium and vertigo might have been related to vestibular organs. Barany first mentioned positional vertigo and otolithic disease in 1921, and Dix and Hallpike defined their clinical characteristics in 1952. After studies from numerous otologists and neurologists, including Schuknecht and Epley, which identified benign paroxysmal positional vertigo (BPPV) has emerged as one of today's most common diseases. The development of various test methods enabled more detailed diagnosis of BPPV. The treatment performance also improved significantly as various canalith repositioning procedures were introduced.

Korean J Otorhinolaryngol-Head Neck Surg 2021;64(7):457-66

Key Words Benign paroxysmal positional vertigo $\cdot$ Vertigo.

\section{서 론}

현기(vertigo)에 대해 기원전 4세기에 히포크라테스(Hippocrates of Cos)는 편두통과 연관하여 설명하였으며, 서기 2세기경에 아레테우스(Aretaeus of Cappadocia)는 간질과 밀접한 관계가 있다고 설명하였다. 이러한 개념은 14 16세기 르네상스 시대에도 변하지 않아 현기를 간질 발작과 연관 짓 거나, 심지어 뇌 심실에서 증기가 소용돌이쳐 생기는 현상으 로 설명하는 등 뇌 질환 증상 중 하나로 보았다. 18세기까지 전정기관이 청각을 담당하리라는 인식도 변함이 없었다. 평 형감각과 현기가 전정기관과 관련 있으리라는 인식은 19세기 부터 비롯되었다.

This is an Open Access article distributed under the terms of the Creative Commons Attribution Non-Commercial License (https://creativecommons.org/licenses/by-nc/4.0) which permits unrestricted non-commercial use, distribution, and reproduction in any medium, provided the original work is properly cited.
본문은 르네상스 이후 내이 해부에서 전정기관 생리, 현기 병리와 그 임상 적용에 이르기까지 변천 과정을 뒤돌아보고 그 중에 두위 현기(positional vertigo)가 양성발작성두위현기 (benign paroxysmal positional vertigo, BPPV)로 부각되는 과정을 살펴보고자 한다.

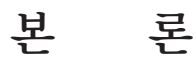

16세기

14 16세기에 서유럽은 신에서 벗어나 인간 중심으로 문예 부흥을 추구한 이른바 르네상스 시대를 맞는다. 특히 문화예 술계에서 인간 재발견이라는 풍조가 일면서 회화와 조각에는 인체 근육과 뼈, 관절 움직임까지 생생하게 묘사되었고, 이는 자연스럽게 해부학 발전으로 이어진다. 인체 해부는 르네상스 문화를 꽃피운 이탈리아 피렌체를 중심으로 전개되었다. 해 
부대 위에서 인체 비밀은 하나둘씩 드러나기 시작하였으며 16 세기에 이르러 내이도 서서히 모습을 드러낸다.

내이 구조를 최초로 상세히 기술한 인물은 이탈리아 파도 바 대학에 가브리엘 팔로피오(Gabriele Falloppio)다. 1561년 에 팔로피오는 저서 『관찰 해부학`에서 고막부터 이소골, 난 원창과 정원창을 거쳐 와우와 전정, 세반고리관, 청신경과 고 삭신경에 이르기까지 내이 구조 대부분을 정교하게 묘사했다. 이때 팔로피오는 전정과 세반고리관을 미로라 부르며 와우와 구분하였다. 39 세 짧은 생애에 팔로피오가 해부 분야에서 이 룬 성과는 실로 대단하여 지금도 Fallopian(facial) canal, Fallopian(ovarian) tube 등에 이름이 남아있다. ${ }^{1)}$

팔로피오와 동시대에 이탈리아에는 바르톨로메오 유스타 키(Bartolomeo Eustachi)라는 걸출한 해부학자가 있었다. 유 스타키는 이관을 비롯해 중이 구조와 고막장근신경, 와우 나 선형 구조와 와우축 등 내이 구조를 파헤쳐 팔로피오에 버금 가는 업적을 남겼다. 그러나 유스타키가 쓴 원고와 해부도를 새긴 동판은 유스타키 사후에 분실되었다가 160 여 년이 지난 18 세기 초에 동판만 발견되면서 그제야 업적이 재조명되었다. 지금도 통용되는 Eustachian tube라는 이름도 이탈리아 볼 로냐 대학에 안토니오 발살바(Antonio Maria Valsalva)가 유 스타키를 기려 붙인 이름이다. ${ }^{2)}$

\section{7세기}

팔로피오 이후 내이 전정 구조가 비교적 상세히 밝혀짐에도 전정 기능에 대한 이해는 여전히 청각에 머물러 있었다. 17세 기 말엽에 유럽 최초 이과 의사로 명성이 높았던 프랑스 과 학학술원에 해부학자 귀샤르 뒤베흐네(Guichard Joseph Du Verney)조차도 전정기관에 좁은 미로는 고음을, 넓은 미로는 저음을 받아들이며 반고리관에 팽대부는 소리를 증폭시키는 트럼펫 역할을 한다고 잘못 이해하였다. 이렇게 본 까닭에는 전정기관만 가진 어류가 소리에 반응함에 유추한 것이기는 하나, 실제로 어류에도 와우와 유사한 소낭(lagena)이 있음을 간과한 것이었다. ${ }^{3}$

\section{8세기}

18 세기경부터는 독일, 이탈리아를 비롯해 서유럽에서 출판 업이 성황을 이루면서 다양한 전문 서적이 출판되어 나왔다. 독일 국립과학학술원에 해부학자 요한 쿨무스(Johann Adam Kulmus)는 1722년에『해부도감』을 편찬하였는데 초판부터 프랑스와 네덜란드 등에 번역되어 나갔다. 그 중에 네덜란드 어판은 일본까지 전해져 오바마 번(小浜藩, 현재 후쿠이 현) 에 의사 스기타 겐파쿠(杉田玄白)가 이 책을 번역해 1774년에 『해체신서」를 출간하였다. 서양의학 용어 대부분이 이때 한자
로 지어져 일부는 지금도 통용되고 있다. 하지만 당시 일본 막 부정권은 서양도서를 금서로 취급했기에『해체신서』는 스기 타 가문이 운영한 사숙(私塾)을 통해 읽혔을 뿐 제대로 알려 지지 않았다. 이 책에서 스기타는 내이 미로를 다음과 같이 번역하였다.

‘회곽(回郭, 내이)은 휘어진 관이다. 바깥 청골(聽骨, 이소골)과 맞 닿은 곳이 포루타루(ポルタール, portal)인데 회곽 안으로 움푹 들어 가 있다. 와우각과 삼반규관이 서로 마주보고 있고, 삼반규관 다섯 개 구멍이 포루타루로 열려 와우각과 통한다. 핫로피토스 수관(ハッ 口ピトス水管, Fallopian aqueduct, 안면신경관)은 회곽에서 끝나는 데, 석골(石骨, 추체골)에서 시작해 구부러지고 돌아서 완골(完骨, 유 양돌기)에 구멍으로 빠져나온다. 그 안으로 신경이 지나간다.'4)

여기서 vestibule을 portal로 표기한 것으로 보아 유럽에서 vestibule이라는 이름은 이후에 지어진 것으로 보인다. 라틴 어로 vestibulum은 고대 그리스 로마시대에 건축구조 용어이 며, 현관과 중문 사이에 놓인 입구를 뜻한다.

18 세기에 들어 현미경은 빛 굴절 차이에서 생기는 이미지 왜곡(색수차) 문제가 해결되면서 더욱 미세한 관찰이 가능해 져 의학 발전에 크게 기여하였다. 1761년에 이탈리아 나폴리 난치병원에 도미니코 코투뇨(Domenico Felice Antonio Cotugno)는 골 미로에서 전정수도관과 와우수도관을 발견하 였는데, 두 수도관이 지주막하 공간과 연결되어 있으면서 젖 어있음으로 보아 내이는 액체로 차 있다고 발표하였다. 이는 내이에는 정제된 공기가 차 있으리라는 당시 통념을 깬 발견 이었다. 아울러 코투뇨는 음파가 이 액을 통해 특정 와우 기 저막에 전달될 것이라는 와우 공명론도 제기하였다. ${ }^{4}$

코투뇨 림프액이 발견되고 이어서 내이 막 미로 구조도 드 러나기 시작했다. 이탈리아 파비아 대학에 안토니오 스카파 (Antonio Scarpa)는 1789년 골 미로 속에서 막 미로를 최초 로 분리해내었다. 아울러 전정을 난형낭과 구형낭으로 구분 하였으며, 막 미로는 전정 안쪽으로 세 반고리관까지 이어지 고, 전정 바깥쪽으로는 와우관으로 이어져 와우공을 통해 골 미로와 서로 교통함을 밝혀내었다. 이때 스카파와 코투뇨가 발견한 림프액은 각각 내림프액과 외림프액으로 구분되었다. 마침 바로 직전 해에 독일 괴팅겐 대학교에 의학대학원생인 사무엘 쇰머링(Samuel Thomas von Sömmerring)이 당시 9쌍으로 나눠져 있던 뇌신경을 처음으로 12 쌍으로 분류하면 서 안면신경과 청신경을 따로 분리하였는데, 이어서 스카파는 청신경을 전정신경과 와우신경으로 구분하였다. 아울러 전정 신경과 연결된 난형낭반(macula utriculi)과 구형낭반(macula sacculi), 그리고 팽대부릉(crista ampullaris)을 식별해내 
는 등 스카파는 전정생리학에 새 지평을 여는 데 크게 기여 하였다. 다만 스카파 역시 전정신경은 청신경에 한 지류로 보 았으며, 여전히 청각을 담당하리라는 관점에서는 벗어나지 못했다. ${ }^{5)}$

\section{9세기}

18세기 후반에 코투뇨가 외림프액을, 스카파가 막 미로와 내림프액을 발견하면서 전정기관 생리 연구는 새로운 국면에 접어드는 듯했다. 하지만 19 세기에 접어들어서도 여전히 와 우는 소리 높이를, 구형낭과 난형낭은 소리 크기를, 세반고리 관은 소리를 모으고 소리 방향을 감지하는 청각기관으로 이 해하고 있었다.

이런 가운데 반고리관이 신체 평형과 관련 있다는 첫 연구 결과가 나왔다. 이를 제기한 인물은 프랑스 파리에서 활동 중 이던 생리학자 피에르 플로렌스(Marie Jean Pierre Flourens) 였다. 애초에 플로렌스는 동물실험을 통해 소뇌 기능을 주로 연구하면서 별도로 내이에서 청각을 담당하는 핵심 부위를 찾아내고자 하였다. 비둘기 실험에서는 고막과 등골을 제거 하고 난원창을 통해 전정과 와우 기저부를 차례로 파괴해 들 어가면서 각 부위가 청각에 어떤 영향을 미치는지 확인하고 있었다. 그러던 중 측반고리관을 자극하는 순간 비둘기가 갑 자기 격렬하게 머리를 흔들어대는 기이한 현상을 발견하였으 니, 새로운 진리 세계가 열리는 순간이었다. 플로렌스는 이 경 이로운 경험을 1825 년에 저서 『신경계 경험」을 통해 다음과 같이 밝혔다.

'나는 비둘기 측반고리관을 열어 바늘 끝으로 찌를 때마다 비둘기 는 매우 날카로운 통증을 느끼고 반복할수록 더 괴로워하는 현상을 발견하였다. 이보다 더 특이한 현상은 찌를 때마다 비둘기가 갑작스 럽고도 매우 거칠게 머리를 좌우로 흔들어댄다는 것이었다. 이 사실 은 직접 보지 않고는 믿기 어려울 정도였다.

이 기이한 현상을 더 자세히 살피고자 나는 아주 미세한 가위로 측반고리관 양쪽 모서리를 잘라보았다. 이때도 비둘기는 고통스러워 하면서 머리는 상상할 수 없는 속도로 오른쪽 또는 왼쪽으로 흔들어 댔다. 이 머리 동요는 가끔 멈추기도 하나 걷자마자 곧바로 다시 생 기고, 움직임이 커질수록 점점 더 세어져 통제 불가능한 상태가 되 기도 했다. 이때는 똑바로 서지 못하고 균형을 잃고 넘어져 오랫동안 몸을 구르거나 몸부림쳤다.

이 현상은 내가 소뇌를 절제했을 때 관찰한 평형 상실 현상과 매 우 흡사해 측반고리관 제거 때 혹시 소뇌에 손상을 주지 않았을까 싶어 주의 깊게 소뇌를 검사했지만 완전히 정상 상태였다. ${ }^{6)}$

동시에 플로렌스는 비둘기 눈과 눈꺼풀도 심하게 요동치는
현상을 관찰하였으나 더 이상은 파고들지 못했다. 이 실험에 서 반고리관 절단 부위에 따라 머리와 몸이 독특한 방향으로 움직임으로 미루어보아 플로렌스는 반고리관이 신체 운동에 관여하는 운동기관이라고 인식하였다. 그리고 이 운동은 소 뇌가 지배한다고 결론지었다. 이러한 오류에도 불구하고 플로 렌스가 반고리관을 특정하여 청각보다는 평형감각과 관련 있 음을 밝혀낸 업적은 전정기관에 대한 인식을 완전히 바꿔버 렸다는 점에서 매우 높이 평가 받았다.

현기에 대해 다른 의미 있는 연구도 이즈음에 나왔다. 1827년 프로이센 브레슬라우 대학(현재 폴란드 브로츠와우 대학)에서 유럽 최초로 생리학과를 개설한 요한 펄킨예(Johann Evangelist Purkinje)는 사람을 회전시킨 뒤에 두위를 변환시키면 눈앞에 보이는 물체 회전 방향이 변하는 현상을 발견하고는 이 현상을 소뇌와 연관 지어 설명하였는데," ${ }^{7)}$ 이는 곧 두위 현 기를 최초로 언급하였다는 점에서 가치가 있었다.

1861년에는 현기가 내이 병변으로 생긴다는 첫 임상사례 보고가 나왔다. 프랑스 파리에 국립농아학교 수석 교의 프로 스퍼 메니에르(Prosper Ménière)는 지난 20여 년간 소문을 듣고 찾아오는 난청 환자 중에 현기 발작이 주기적으로 생기 면서 이명과 편두통에 속이 메스껍거나 토하면서 쓰러지기까 지 하는 환자를 다수 접하고는 이러한 증상을 일으키는 어떤 기질성 병변이 분명히 있을 것으로 내다보았다. 게다가 과거 이 증상을 겪다 사망한 한 소녀를 부검하여 반고리관 안에서 흘러나온 혈성 림프액을 발견한 경험도 있었기에 메니에르는 반고리관에 병변이 난청과 현기를 일으키리라는 심증을 굳힌 지 이미 오래였다. 마침내 메니에르는 1861년 파리 제국의학 학술원에 출석하여 실조성 뇌울혈(apoplectiform cerebral congestion)과 유사한 증상을 일으키는 내이 병변에 대해 그 동안 연구해온 결과를 발표하였다. ${ }^{8)}$

'저는 오래 전에 환자 몇 명을 관찰한 적이 있었습니다. 그런데 모 두가 한결 같고도 심각한 증상을 갖고 있어 혹시 우리가 어떤 한 기 질성 병변을 놓치고 있지 않나? 하는 의문을 갖게 되었습니다. 증상 이 짧게는 몇 주에서 길게는 몇 년을 끌다가 갑자기 사라지는 바람 에 어쩌면 우리가 이 병변을 지나쳤을 수도 있겠습니다. 과거 플로렌 스가 비둘기 반고리관을 절단하여 비둘기가 회전하면서 평형을 잃는 다는 사실을 실험에서 보여주었듯이, 이를 사람에게도 적용하여 현 기, 메스꺼움, 구토, 쓰러짐 등이 생긴다면 이 기능장애가 내이 미로 에 어떤 변화로 생긴 것이라 추론할 수 있지 않을까요? 물론 뇌척수 막 울혈과 같은 뇌질환 또는 소뇌 일부 및 부속 질환에서도 생길 수 도 있겠습니다. 그럼에도 끊이지 않는 여러 소음과 눈에 띨 정도에 난청이 뒤따르는 것으로 보아 병소는 미로, 그 중에도 반고리관에 있 다고 보아야 할 것입니다.'9) 
그리고 이 한 해 동안 메니에르는 자기 주장을 뒷받침할 나 머지 사례를 파리의학관보에 세 차례 더 보고하였다. 메니에 르 주장은 과거 플로렌스가 반고리관이 신체평형과 관련 있 다고 발표한 학설에 근거하여 반고리관 병변이 현기를 일으킨 다는 첫 임상보고였다는 점에서 작지 않은 파장을 불러 일으 켰다. 그럼에도 당시 의학계는 여전히 현기를 간질을 일으키 는 뇌질환 증상 중 하나라고 보았기에 메니에르 주장을 받아 들이기가 쉽지 않았다.10)

이렇듯 플로렌스 연구보고가 메니에르를 비롯한 여러 전정 생리 연구가에게 신개념을 제공한 것은 분명했다. 플로렌스 이후 약 반세기가 지나 반고리관에 비밀을 풀어줄 보다 구체 적인 학설이 나왔다. 1870년 독일 마르틴 루터 대학 생리학과 에 프리드리히 고츠(Friedrich Leopold Goltz)는 머리가 움 직일 때마다 반고리관에 팽대부릉정은 내림프액 무게를 받 게 되고 이를 전정신경이 감지하여 신체평형을 잡게 된다는 소위 유체정체설(hydrostatic theory)을 내놓았다. ${ }^{1)}$ 이는 반고 리관을 운동기관으로 본 플로렌스와 달리 반고리관을 머리 자세를 감지하는 감각기관으로 본 첫 보고였다. 아울러 고츠 는 평형감각을 인간 오감에 보태어 여섯 번째 감각이라고 하 였다.

그리고 3년 뒤 1873년에는 수정된 학설이 나왔다. 체코 프 라하 카렐 대학 물리학과에 엔스트 마하(Ernst Mach)는 오 스트리아-헝가리 제국 과학학술원에서, 그리고 오스트리아 빈에서 개원 중이던 요젭 브로이어(Josef Breuer)는 오스트리 아-헝가리 제국 의학예비학회에서 거의 동시에 유체역동설 (hydrodynamic theory)을 발표하였는데, 머리를 움직이면 반 고리관에 내림프액도 함께 움직이면서 자세를 감지하게 된다 는 가설이었다. 다만 마하는 회전의자 실험에서 내림프액 흐 름은 매우 제한적이며 오히려 내림프액 압력을 강조함으로써 고츠와 크게 다르지 않았다면, 브로이어는 동물실험을 통해 압력보다는 흐름을 더 강조하였다는 점에서 차이가 있었다.11)

여기서 브로이어는 한걸음 더 나아가 어류, 파충류와 조류 에서 난형낭과 팽대부릉에 독특하게 생긴 유모세포를 관찰 하였는데 모든 척추동물은 고개를 움직일 때 내림프액 흐름 에 맞춰 낭형낭반에 막과 팽대부릉정이 따라 움직이고, 이때 유모세포 섬모가 굽어지면서 전정신경 수용체를 자극하면 뇌가 자세를 인식하고 평형을 유지한다고 설명하였다. 이는 당시 배율이 낮은 광학현미경을 사용해 얻어낸 실로 놀라운 결과였다. 아울러 평생을 전정 연구에 매진한 브로이어는 전 정은 선 가속 운동을, 반고리관은 각 가속 운동을 감지하고 이때 반사적으로 나타나는 눈 흔들림 등 수많은 이론을 제시 하였다. 이중에서 내림프액 유모세포자극론(shear theory)은 후세 전정생리학 연구에 표본으로 남을 만큼 혁신적인 이론
이었다. ${ }^{12)}$

이어서 유체역동설에 동조한 또 다른 학설이 나왔다. 영국 에든버러 대학 화학 및 약학과에 크럼 브라운(Alexander Crum Brown)은 서로 다른 회전축을 가진 회전의자를 직접 고안하여 여러 각도로 회전시켜 이때 나타나는 눈 움직임에 더 연구초점을 맞추고 있었다. 그 결과 1874년에 브라운은 좌 우 반고리관 중 같은 축(또는 평면)을 가진 두 반고리관은 서 로 짝을 이루며 그 속에 내림프액은 머리 회전 시 서로 대립 방향으로 흐른다고 주장하였다. 그리고 훗날 브라운은 머리 회전 시 반고리관 평면을 따라 눈이 처음에는 회전 반대방향 으로 서서히 움직이다가 이내 시계 초침처럼 회전방향으로 급히 쫓아간다고 설명하였는데, 당시 이 설명은 제대로 이해 되지 않았다. 이는 후세에 내림프액 흐름에 따라 느린 성분과 빠른 성분을 가진 안진 성상으로 밝혀지면서 비로소 제대로 평가 받게 된다. ${ }^{13)}$

브라운과 비슷한 연구 결과가 또 뒤를 이었다. 헝가리 페렌 요제프 대학 약학과에 엔드레 흐게스(Endre Hőgyes)는 직 접 고안한 회전 테이블 위에서 토끼를 회전시켜 반고리관을 자극하는 방식으로 일으킨 눈 움직임을 관찰하였다. 이 실험 에서 흐게스는 토끼 두 눈이 회전하는 반고리관 평면을 따라 함께 움직임을 발견하고는 1881년에 전정 미로와 특정 외안 근이 서로 연계되어 있으며 이와 관련된 중추부가 있음을 발 표하였다. 이는 머리 회전에 따라 나타나는 안진을 반고리관 과 외안근을 특정하여 설명한 것으로 훗날 전정안반사(vestibulo-ocular reflex)로 밝혀지게 된다. 하지만 흐게스 학설 도 당시에는 널리 알려지지 않아 후대에 가서 인정받게 된다. ${ }^{14)}$

광학현미경이 상용화되면서 배율도 크게 높아지자 스웨덴 스톡홀름 카롤린스카 의대 조직학과에 구스타프 레치우스 (Gustaf Retzius)는 1881년 모든 종에 동물 난형낭반에서 전 정감각상피 구조를 관찰하여 결과를 발표하였는데, 전정신 경 말단 형태에 따라 유모세포는 둥글거나 막대 모양을 가진 두 가지 형태가 존재하며 섬모는 젤리 성분을 가진 막에 묻 혀있다고 하였다. 그 결과 머리가 움직이면 난형낭반에 막이 젤리 미끄러지듯 따라 움직이면서 섬모를 자극한다고 밝혀 브로이어가 주장한 유모세포자극론에 힘을 실어주었다. ${ }^{15)}$

이즈음에 프랑스 스트라스부르 대학에 엔스트 이발트(Ernst Julius Richard Ewald)는 독일에서 건너온 고츠 교수 조수로 지내면서 와우와 전정 기능을 연구하고 있었다. 수많은 실험 을 거듭한 끝에 1892년에 『옥타부스(여덟 번째) 신경 말단기 관에 대한 생리학적 조사라는 저서를 내놓았는데, 내용은 플로렌스부터 고츠, 마하와 브로이어, 흐게스 등이 제시한 이 론을 동물실험으로 면밀하게 검증한 것이었다. 이 중에서 비 둘기 반고리관 골 미로에 구멍을 내어 공압망치(pneumatic 
hammer)로 막 미로를 눌렀다 떼는 방식으로 내림프액 흐름 을 일으켜 이때 생기는 안진에 대해 관찰하였는데, 이 실험은 플로렌스 이후 반고리관 실험에서 누구도 시도하지 못한 크게 진일보한 방식이었다. 아울러 이발트 실험은 반고리관에 대한 수많은 기존 연구와 가설을 역동적으로 직접 증명해 보였다 는 점에서 비상한 관심을 받았다.

'머리 회전은 좌우 반고리관 한 쌍에 작용한다. 특히 수평으로 회 전한 경우, 좌우 두 측반고리관 팽대부에 작용하되 회전한 쪽 팽대부 에 더 강한 영향을 미치며, 또한 이 팽대부에 인접한 눈이 더 강하게 영향을 받는다. ${ }^{16)}$

비록 간결한 언급이었지만 이 설명은 많은 연구가에게 소위 이발트 3법칙으로 정리되어 검증을 받게 된다. 즉 머리 회전 시 안진 방향은 영향을 받는 반고리관 축(또는 평면)과 일치 하며(1법칙), 내림프액이 측반고리관에서 팽대부로 흐를 때 (ampullopetal flow) 전·후반고리관에서는 팽대부 반대로 흐 를 때(ampullofugal flow) 흥분반응이 생기며(2법칙), 한쪽에 흥분반응은 반대쪽에 억제반응보다 더 강하게 작용한다는 (3법칙) 법칙이었다. 이 중에 1,3 법칙은 앞서 여러 연구자에 의해 이미 거론된 내용이기에 논란이 적었으나 2 법칙에 대해 서는 논란이 크게 일었다. 이 논란은 수십 년간 계속된다.

\section{0세기}

19 세기 중엽부터 중국과 일본에는 서양의학이 본격적으로 유입되고 있었다. 대한제국이 서양문물에 개방정책을 쓰기 전부터 다양한 서양의학 서적이 들어와 있었는데 해부학 서 적으로는 청나라에서 활동 중이던 영국인 의료선교사 벤자 민 합슨(Benjamin Hobson)이 한자로 펴낸 해부학서『전체신 론』과 영국에 해부학자 헨리 그레이(Henry Gray)가 쓴 영어 판 『그레이 해부학』 등이 국내에 들어와 있었다. 하지만 본격 적으로 의학교재로 활용된 해부학서는 1906년에 제중원의학 교에 의학도 김필순과 학교장 올리버 에비슨(Oliver R. Avison)이 펴낸『해부학』이 최초다.

‘막양 미로는 골양 미로와 같이 있어 이것을 전정과 삼반규관과 와우각 부위라 부른다. 막양 미로는 투명하고 심히 얇은 결합조직막 이니 미세혈관과 신경이 있고, 내면에는 편평상피가 있고 내림프를 함유한다. 전정 미로는 타원낭과 정원낭, 내림프관 세 부분을 일컫는 데 두 낭 내벽은 전정 골 면에 붙어 두꺼워져 청반(聽班, macula acausticae)이라 부르니 곧 전정신경이 뜷고 들어간 곳이다. ${ }^{17)}$

이 책은 일본 도쿄 제국대학 해부학과에 이마다 쓰카누(今
田束)가 쓴『실용해부학』을 번역한 책인데 원본 역시 19세기 중반에 유럽에서 출판된 여러 해부학 책을 옮긴 것이라 당시 에 의학 수준을 엿보게 한다. 1774년에 일본어판『해체신서』 에서 내이 골 미로까지 소개되었다면 130여 년이 지난 한글 판『해부학』에는 막 미로까지 상세히 소개되어 있다. 다만 난 형낭반과 구형낭반을 청반으로 표기한 것으로 보아 이 구조 가 평형감각보다는 여전히 청각을 담당하는 것으로 본 것인 지는 이 책 내용만으로는 알기가 어렵다. ${ }^{18)}$

1861년 메니에르 발표 이후에도 현기를 전정기관 병리와 연 계하여 임상에 적용하기까지는 많은 시간과 노력이 필요했다. 20 세기에 접어들어 이를 최초로 선도해간 인물이 바로 헝가 리 계 오스트리아 의사 로베르트 바라니(Róbert Bárány)였다. 바라니는 오스트리아 빈 대학 이과 교수 아담 폴리처(Adam Politzer)가 운영하는 이과 의원에서 전정기관 생리와 병리 연 구에 집중하고 있었다. 특히 회전의자를 이용하거나 냉·온수 를 귀에 주입해 나타나는 안진을 분석하여 현기 진단에 활용 하고 있었는데, 이때 생기는 칼로리 반응을 바라니는 반고리 관 막 미로에 생긴 내림프액 대류현상이 팽대부 감각기를 자 극한 것으로 설명하였다. ${ }^{19)}$

사실 칼로리 반응은 바라니가 처음 언급한 이론은 아니었 다. 하지만 바라니는 칼로리 반응을 임상에 적용해 현기라는 주관적 증상을 안진이라는 객관적 징후로 검증하였다는 점 에서 높은 평가를 받았으며, 이로써 1914년 노벨 생리·의학상 수상자에 지명되는 영예를 안았다. 하지만 바라니는 제 1 차 세 계대전에 종군하다 러시아 포로수용소에서 지명 소식을 들었 으며, 스웨덴 왕실과 적십자사 협상으로 1916년에 석방되어 노벨상을 수상하였다. 그 인연으로 바라니는 이듬해 스웨덴 웁살라 대학에 초대 이과 교수로 초빙되어 전정기관 연구를 이어갔다.

1921년에 바라니는 매우 의미 있는 사례를 보고하면서 다 시 한 번 의학계에 큰 이목을 끈다. 바라니는 일정한 자세에 서만 현기와 안진을 보이는 27세 한 여성을 사례로 보고하면 서 이 여성이 않고 있는 두위 현기가 이석 질환(otolithic disease)이라고 처음 언급한 것이었다.

‘현기 발작은 이 여성이 오른쪽으로 누울 때만 나타났으며 그때 오른쪽으로 강한 회전성 안진이 나타났다. 발작은 약 30 초간 지속되 었고 격심한 현기와 메스꺼움을 동반했다. 이 증상들이 사라진 직후 에 고개를 다시 오른쪽으로 돌리면 아무런 발작이 일어나지 않았고, 새로운 발작을 일으키려면 한동안 환자는 똑바로 눕거나 왼쪽으로 돌아누워 있어야 했다.'

수세기 전부터 어류, 양서류, 파충류 전정에서 이석은 잘 알 
려져 있었고, 심지어 일부 어류에서는 이석 골편을 육안으로 도 볼 수 있어 이들 전정을 이석기관이라 부르기는 했지만 조 류와 포유류 전정에서는 여전히 이석이 발견되지 않았기에, 바라니는 인간 전정 역시 단순히 이석기관으로 예단하여 두 위 현기를 이석 질환 증상이라 불렀을 뿐 과연 전정 어디에 어떤 문제로 현기를 일으키는지는 알지 못했다. 이는 바라니 가 보고 말미에 건넨 화두에서도 확인된다.

'이제부터 우리가 해야 할 일은 머리를 빠르게 움직였을 때 생기 는 안진 발작이 이석 기관에서 생기는 것인지 그리고 다른 어떤 증 상들이 이석 기관과 연관되는지를 확인하는 것이다. ${ }^{20)}$

바라니 이후 현기에 대한 많은 연구와 발표가 잇달아 나왔 는데 이 중에 매우 의미 있는 연구 결과가 나왔다. 1938년에 영국 런던에 미들섹스 병원 부속 페렌스 연구소 이과에 찰스 홀파이크(Charles Skinner Hallpike)가 메니에르 증후군이 내림프액 수종으로 발병함을 조직병리학적으로 규명해낸 것 이다. ${ }^{21)}$ 그 이전에도 메니에르 증후군 원인이 와우 내압 상승 과 내림프관 폐쇄일 것이라는 연구가 꾸준히 나왔고, 이에 따 라 이미 내림프낭 감압술이 시도되기도 하였지만 확증은 없 었기에 홀파이크 규명은 의미가 매우 컸다. 이로써 메니에르 병은 내림프액 수종을 일으키는 대표적 질환으로 자리 잡게 된다. 공교롭게도 같은 해에 일본 오사카제국대학 이비인후 과에 야마가와 교시로(山川強四郎)도 홀파이크와 같은 조직 병리 결과를 내놓았으나 제2차 세계대전 혼란 속에서 일본이 패전하면서 부각되지 못한 채 잊히고 말았다. ${ }^{22)}$

1952년에 홀파이크는 퀸스퀘어 국립병원 이비인후과 여의 사 마가렛 딕스(Margaret Ruth Dix)와 함께 또 다시 매우 중 요한 두 가지 임상결과를 내놓는다. 그 중 하나는 메니에르병 외에 현기를 일으키는 대표적 질환으로 전정신경염을 제시한 것이다. 두 사람은 지난 6년 동안 메니에르병과 구별되는 또 다른 현기 발작에 대해 주목해오던 중 이 현기 발작이 매우 돌발적으로 나타나면서 와우 증상과 징후가 없는데다 칼로리 반응에서 현격한 좌우 차를 보인다는 점에서, 의심할 여지없 이 전정신경계 질환이 분명하나 명확한 병리를 알지 못해 우 선 포괄적 용어로 전정신경염이라 부를 것을 제안하였다.

또 다른 하나는 특정 두위를 취했을 때 공통된 현기와 안 진을 보이는 환자 100 예를 분석하여 과거 바라니가 언급한 두위 현기에 대한 그 임상적 특성을 규명한 것이었다. 즉 대 상 환자에서 두위 현기는 수주에서 수개월 후 저절로 사라지 기도 하는 순한 성질을 가졌으며(benign), 두위 변환(positional)에 갑작스레(paroxysmal) 생기는 공통점이 있다고 설 명하였다.
'먼저 환자를 침상에 반듯이 누이되 침상 끝에서 머리가 바닥 쪽 으로 30 도 기울어야 하고 고개는 한쪽으로 30 45도 돌려져 있어 야 한다. 그러기 위해서는 먼저 환자가 침상에 앉은 자세에서 고개 를 한쪽으로 돌려 검사자 이마를 쳐다보게 하고, 검사자는 두 손으 로 환자 머리를 단단히 잡고 재빨리 뒤로 눕혀야 한다. 이때 안진은 언제나 분명한 잠복기 후에 나온다. 때로는 잠복기가 매우 짧아서 곧바로 나타나기도 하지만 이는 드물다. 안진이 나오기 전에 언제나 환자가 먼저 놀란다. 안색이 변하고, 눈을 감으려 하고, 소리를 지르 며, 일어나 앉으려고 한다. 이때 환자를 안심시키고 머리 자세를 유 지하도록 한다. 안진은 주로 바닥 쪽 귀를 향해 회전한다. 회전방향 은 각막 둘레를 시계로 보아 12시를 기준으로 삼는다. 안진에는 회 전성분 외에도 수평성분도 있어 바닥 쪽 귀로 향하는 것이다. 안진 은 2,3 초에서 10 초 정도는 빨라지다 급격히 늦어지고 이때 환자도 진정된다. 환자를 일으켜 세우면 다시 약한 안진이 나타나는데 방 향은 역전된다. 안진이 사라지기를 기다렸다가 다시 눕히면 안진이 나타나지만 대개는 이전보다 약하고 곧 사라진다. 이런 식으로 두 세 번 더 검사했다가 잠시 쉬면 과거 바라니가 지적했던 것처럼 더 이상 이런 반응은 나타나지 않는다.

이 설명은 훗날 양성발작성두위현기가 지닌 말초성 두위 현기와 안진 특성을 고스란히 담아낸 것이었다. 즉 현기와 안 진은 특정 두위에서 잠복 후에 나타나고, 짧게 지속되는 동안 자각증상이 심하면서, 이때 생긴 회전성 안진은 몸을 일으켜 세우면 방향이 역전되고, 또 다시 뉘이면 현기와 안진이 약해 지거나 사라지는 피로현상을 설명한 것으로 당시로서는 매우 놀라운 발견이었다. 그럼에도 딕스와 홀파이크는 보고 말미에 다음과 같은 의문을 제기하였다.

'분명한 점 두 가지가 있다. 첫째로, 이 질환은 병리가 어디에서 어 떠하든 간에 본질이 양순하고 또 저절로 가라앉는다는 점이며, 둘째 로 본질이 어떠하든 간에 이 질환은 전정기관에서 일어난다는 점이 다. 여기서 전정이라 함은 미로와 전정신경 그리고 그 중추 연결 부 위까지 포함한다. 그렇다면 이 질환은 도대체 어디에서 생겼으며, 본 질은 또 무엇이란 말인가? ${ }^{23)}$

딕스와 홀파이크가 두위 현기를 전정 질환 중 하나로 확신 은 하면서도 명확한 병리를 알지 못했음은 과거 바라니 경우 와 크게 다르지 않았다. 다만 두위 현기를 일으키는 자세를 특정하였고 이때 나타나는 안진 특성을 밝혔다는 점에서는 바라니보다 매우 진일보한 결과였다. 그리고 제시된 두위변환 법(Dix-Hallpike maneuver)은 70년이 지난 지금까지도 수정 없이 양성발작성두위현기 진단에 활용되고 있으니 두 연구자 가 향후 이석 질환 연구 활성화에 얼마나 크게 기여하였는지 
는 이루 말하기 어려울 정도다.

그 이듬해 1953년에는 스웨덴 스톡홀름 카롤린스카 의대 조직학과에 디에고 칼스트룀(Diego Carlström) 등은 전자현 미경과 $\mathrm{X}$ 선 회절법을 이용하여 인간을 비롯한 척추동물 난 형낭반과 구형낭반 표면에서 이석 무리를 발견하는 계가를 올렸다. 즉 이석은 길이 1 20 $\mu$, 지름 1 8 $\mu$ 에 육각형 형태를 가졌으며 방해석 성분으로 된 탄산칼슘 결정체라고 발표하 였다. 이는 그동안 인간에게도 존재하며 신체 평형에 관여하 리라 여겨온 평형사(statoconia)를 그 성분과 형태까지 증명 해 보인 발견이었다. ${ }^{24,25)}$ 그럼에도 평형사가 두위 현기와 어떤 연관이 있는지는 여전히 풀어야 할 숙제로 남았다.

이어서 1954년에 카롤린스카 의대 이비인후과에 얀 베셀 (Jan Olof Wersäll) 등은 기니피그에서 난형낭반 미세구조뿐 만 아니라 반고리관 팽대부릉에서 1,2 형 유모세포와 운동모 (kinocilium), 부동모(stereocilia) 배열을 관찰해 발표하였 다. ${ }^{26,27)}$ 여기서 측반고리관에 유모세포 운동모는 난형낭 쪽으 로 배열되어 전·후반고리관 운동모와 상반된 배열을 보인다 고 하였다. 이 결과로 이후 내림프액 흐름에 운동모와 부동모 가 어느 한쪽으로 쏠리면 유모세포에는 탈분극 또는 과분극 에너지가 생기고 이 전기 에너지가 중추를 거쳐 전정안반사 운동을 일으킴이 신경생리학적으로 증명되었다. 뿐만 아니라 지난 70 여 년간 논쟁 속에 휩싸인 이발트 2 법칙도 모두 정설 로 받아들여지게 된다. 즉 운동모와 부동모 배열이 달라 내림 프액이 팽대부 쪽으로 흐를 때 측반고리관에는 흥분반응이, 전·후반고리관에는 억제반응이 일어난다는 이발트 주장이 옳았음이 증명된 것이다.

인간에게서 전정 이석이 발견되고, 반고리관 팽대부릉에서 흥분과 억제 반응으로 생기는 전정안반사운동이 모두 규명 되면서 두위 현기와 안진에 대해서는 논리적으로 설명이 가 능하게 되었다. 이어서 두위 현기와 관련한 여러 임상 보고가 쏟아져 나왔지만 여전히 과거 딕스와 홀파이크 보고를 확인 하는 수준에 머물렀으며, 두위 현기 병리는 여전히 이석보다 는 전정 신경이나 혈관 문제로 접근하면서 명쾌한 해답을 제 시하지 못했다.

그 실마리를 풀어줄 보고가 1961년에 나왔다. 미국 보스턴 하버드 대학 이비인후과에 초빙된 헤롤드 슈크넷(Harold F. Schuknecht)은 시카고에서 열린 미국 안-이비인후과 학회에 나가 두위 현기가 난형낭반에서 떨어져나간 이석(otoconia)이 중력을 받아 후반고리관 속으로 들어가 일으키는 현상이라고 발표하였다. ${ }^{28)}$ 이는 과거 바라니와 딕스와 홀파이크가 풀지 못한 문제 즉 두위 현기가 과연 전정기관에 문제인지, 그리고 또 그 본질은 무엇인지에 대한 해답을 낸 것이었다. 하지만 너 무나 간단명료한 병리 해석에 오히려 논란을 불러일으켰고,
무엇보다도 반고리관에서 이석을 확인할 길이 없었기에 슈크 넷 해석은 여전히 가설에 불과했다.

결국 슈크넷은 이 가설을 정설로 세우기 위해서는 반고리 관에서 이석을 증명해 보여야 했는데, 마침내 1969년에 두위 현기를 않은 두 사망자 후반고리관 팽대부릉정에 최대 $350 \mu$ 크기에 호염기성 침착물과 막 미로 가장 아랫부분에 과립 같 은 침착물이 층을 이루고 있음을 발견함으로써 자신이 내세 운 가설이 옳았음을 증명해 보였다. 두위 현기가 최초로 조직 병리학적으로 규명되는 순간이었다.

아울러 슈크넷은 두위 변환 시 침착물이 후반고리관 팽대 부릉정을 중력방향으로 휘게 만들어 현기와 안진을 일으킨다 고 설명하면서 이름하여 능정이석론(cupulolithiasis)이라 불 렀다. 그리고 능정이석이 일으키는 현기와 안진은 과거 딕스 와 홀파이크가 설명한대로 잠복기 후 짧은 지속 시간, 심한 자각증상, 회전성과 역전 안진, 피로현상과 같은 특성을 가졌 으며 이는 곧 중추성 현기와 안진과 구별된다고 규정하였다. ${ }^{29}$ 하지만 두위 안진 중 일부는 잠복 없이 나타나고 두위를 유지 하는 내내 지속되면서 반복검사 시 피로현상을 보이지 않는 양상도 보여 이를 중추성 안진으로 보는 등 여전히 의문과 혼 동이 있었다.

한편 슈크넷 등은 연구를 확대하여 1973년에는 능정이석을 보인 149예 측두골을 분석한 결과 후반고리관(84예)뿐만 아 니라 측반고리관(41예)과 전반고리관(24예)에도 능정이석이 존재했다고 발표하였다. ${ }^{30)}$ 이에 덧붙여 고령층에서 능정이석 은 사람을 넘어뜨려 사지뿐만 아니라 생명까지 위협을 줄 수 도 있어 양성 질환이라 부르기에는 적당치 않다고도 하였다. 그럼에도 자신이 내세운 능정이석론이 이석에 대한 연구에 더욱 활기를 불어넣어 점점 양성발작성두위현기(BPPV)라는 병명으로 굳어지는 효과를 내고 말았다.

이즈음 한국도 1972 년에 연세의대 이비인후과에 김영명이 전정기관 해부 ${ }^{31)}$ 서울의대 이비인후과에 노관택이 반고리관 기능검사, ${ }^{32}$ 가톨릭의대 이비인후과에 성창섭이 전기안진검 사에 대해 ${ }^{33)}$ 잇달아 발표하면서 당시 세계 추세와 어깨를 나 란히 했다.

1979년에 캐나다 온타리오 웨스턴 대학 이비인후과에 스테 펜 홀(Stephen F Hall)과 요셉 맥클루어(Joseph A. McClure) 등과 미국 오리건 주 포틀랜드에 이과 개원의사 존 에플리 (John McNaughton Epley)는 능정이석설에 대비되는 관내 이석론(canalolithiasis)을 발표하여 큰 주목을 받았다. 홀은 양성발작성현기 특성 중 하나인 피로현상에 주목하면서 이 현상은 관내이석이 아니고는 설명하기 어렵다고 하였다. 즉 반형낭반에서 떨어져나간 이석 입자가 후반고리관 공통각을 통해 관 속으로 들어가 무리를 지어 내림프액보다 비중이 무 
거운 유동성 관내이석이 되었다가 두위 변환 시 내림프액 흐 름을 일으켜 두위 현기가 생기지만, 두위 변환을 반복하면 입자는 흩어져 내림프액 흐름을 일으키기에는 충분치 않아 현기는 점점 사라진다고 설명하였다. ${ }^{34)}$ 즉 피로현상으로 관내 이석이 존재함을 설명한 것이었다.

한편 에플리는 양성발작성두위현기 환자 29명을 분석한 결과 대다수가 누울 때 외에도 몸을 일으키거나, 허리를 숙이 거나, 고개를 돌리거나, 운전 중 급발진과 급정지하거나 승마 중 머리가 위아래로 요동칠 때도 현기를 경험하는 것은 능정 이석뿐만 아니라 반고리관 내림프액 각 가속을 가중시키는 관내이석이 일으키는 현상으로 보아야 한다고 주장하였다. ${ }^{35)}$ 이후 관내이석은 양성발작성두위현기가 가진 특성 모두와 잘 부합하는 것으로 알려지자 각광을 받았다.

이에 발맞춰 1980년에 독일 에센 크루프 병원 신경과에 토 마스 브란트(Thomas Brandt)와 미국 마이애미 재향군인병 원 신경과에 로버트 다로프(Robert B. Daroff)는 후반고리관 능정이석을 제자리로 되돌리기 위한 습관화 운동을 제시하 였고 ${ }^{36)}$ 이로써 후반고리관팽대부신경절단술과 후반고리관 폐쇄술과 같은 수술은 자연스럽게 사라지게 된다.

이어서 1985년에 맥클루어는 반듯하게 뉘어서 고개를 양쪽 수평으로 돌렸을 때 향지성 방향전환성 수평 안진을 보인 환 자 7명을 보고하면서 이 현상으로 측반고리관에도 관내이석 이 존재함을 설명하였다. ${ }^{37)}$ 그리고 맥클루어가 제시한 방법은 향후 측반고리관 이석 검사법으로 알려지면서 관련된 보고가 이어졌다.

이즈음에 습관화 운동과 차별화한 새로운 후반고리관 이석 치환법이 소개되었다. 먼저 1988년에 프랑스 파리 라히부와 지헤 병원 전정재활의학과에 알랭 시몽(Alain Semont) 등은 능정이석 유리법을 제시하였으며, ${ }^{38)} 1992$ 년에 에플리는 진동 을 곁들인 관내이석 치환법을 제시하였는데 ${ }^{39)}$ 이 방법들은 습 관화 운동보다 적극적이면서도 해당 반고리관에 더 집중한 치 환법으로 지금까지도 널리 쓰이고 있다. 1994년에 브란트 등 은 전반고리관에도 관내이석이 드물게 존재하며 치환은 시몽 이 제시한 유리법을 역으로 시도할 수 있다고 하였다. ${ }^{40)}$ 이후 에플리 방법은 진동 없이 수정되었다.

1995년 미국 로스앤젤레스 UCLA 의대 신경과에 로버트 밸오(Robert W. Baloh) 등은 좌우 측면으로 누울 때 방향전 환성 원지성 안진이 자세를 유지하는 동안 지속된 환자 3 명 을 보고하면서, 이 중 2명은 후반고리관 이석 치환법을 받은 환자로, 그 과정에서 후반고리관 이석이 난형낭을 통해 측반 고리관으로 들어가 팽대부릉정에 부착된 것이며, 따라서 당 시까지 중추성으로 여겨온 지속적, 방향전환성, 원지성 안진 도 말초성 안진으로 보아야 한다고 하였다. ${ }^{41)}$ 이후 이러한 안
진은 측반고리관 능정이석에서 나타나는 특성으로 밝혀지면 서 과거 슈크넷이 제시한 능정이석론은 더욱 힘을 받게 된다.

측반고리관에서 능정이석과 관내이석이 줄지어 규명되자 1996년 독일 베를린 루돌프 피르호 대학병원 신경과에 토마 스 렘퍼트(Thomas Lempert) 등은 270도 회전법, ${ }^{42)}$ 1997년에 이탈리아 피렌체 대학 청각학과에 파올로 반누치(Paolo Vannucchi) 등은 장시간 측와위 고정법, ${ }^{43)} 1998$ 년에 이탈리아 리 보르노 오스페달리리누티 병원 이비인후과에 마우로 구포니 (Mauro Gufoni) 등은 구포니법 ${ }^{44)}$ 을 잇달아 소개하였는데, 지 금은 360도 회전법, 역 구포니법 등으로 진화되어 널리 쓰이 고 있다. 이외에도 2006년에 한국 아주의대 이비인후과에 정 연훈 등은 측반고리관 관내이석 환측 구별을 위해 새로운 검 사법(bow and lean test) ${ }^{45}$ 을 제시하는 등 다양한 진단과 치 환법이 지금도 꾸준히 소개되고 있다.

이렇듯 1921년에 바라니가 처음으로 두위 현기와 이석 질 환을 언급한 이래, 1952년 딕스와 홀파이크가 그 임상적 특 성을 규정하였고, 이후 슈크넷과 에플리 등 수많은 이과 및 신경과 의료진이 노력과 연구를 기울인 끝에 양성발작성두 위현기는 오늘날 현기를 일으키는 가장 흔한 질환으로 부상 하였으며, 더불어 전기안진검사기, 영상안진검사기가 차례로 개발되면서 진단은 더욱 세밀해졌고 이로써 다양한 이석 치 환법이 제시되면서 치료성적도 크게 나아졌다.

한편 전 세계 이과, 이신경학과, 신경학과, 청각학과에 의학 자와 의료진은 바라니 소사이어티(1960), 프로스퍼 메니에르 소사이어티(1981)를 각각 설립하여 학술 교류와 보급에 힘쓰 고 있으며, 증거중심의학에 근거한 임상진료지침을 마련하는 등 전정기관과 현기와 관련한 연구는 지금도 계속되고 있다.

\section{결 론}

의학은 해부와 생리를 근간으로 병리와 임상이 맞물려 발 전하는 양상을 반복해왔다. 각 분야에서 전정기관 연구는 내 이에서 전정 그리고 반고리관으로 압축되어 갔으며, 현기는 메 니에르 병, 전정신경염, 양성발작성두위현기 등으로 세분되어 연구되어 왔다. 이 과정에서 의학계와 의료계가 기울인 헌신 적 노력과 그 결실은 기억해야 할 가치가 충분하며, 그 과정을 이해함은 미래로 나아갈 수 있는 시금석이 되리라 확신한다.

\section{Acknowledgments}

None.

\section{ORCID}

Kee Hyun Park https://orcid.org/0000-0003-4819-437X 


\section{REFERENCES}

1) Wiest G. The origins of vestibular science. Ann N Y Acad Sci 2015; 1343(1):1-9.

2) Hachmeister JE. An abbreviated history of the ear: From Renaissance to present. Yale J Biol Med 2003;76(2):81-6.

3) Desai SS, History of research in the vestibular system: A 400 -yearold story. Anat Physiol 2014;4(2):138-43.

4) Kulmus JA. Kaitai Shinsho (Anatomische Tabellen). vol 2. Sugita G, trans. Edo Nihonbashi: Suharaya Ichibee;1774. p.17-8. Japanese.

5) Van De Water TR. Historical aspects of inner ear anatomy and biology that underlie the design of hearing and balance prosthetic devices. Anat Rec (Hoboken) 2012;295(11):1741-59.

6) Flourens P. Expériences sur le système nerveux, faisant suite aux 'Recherches expérimentales sur les propriétés et les fonctions du système nerveux dans les animaux vertébrés'. Paris: Crevot;1825. p.44-53. French.

7) Cavero I, Guillon JM, Holzgrefe HH. Reminiscing about Jan Evangelista Purkinje: A pioneer of modern experimental physiology. Adv Physiol Educ 2017;41(4):528-38.

8) Jay V. Prosper Menière. Arch Pathol Lab Med 2000;124(2):192-3.

9) Ménière P. Mémoire sur des lésions de l'oreille interne donnant lieu a des symptômes de congestion cérébrale apoplectiforme. Gazette médicale de Paris 1861;32:597-601.

10) Baloh RW. Prosper Ménière and his disease. Arch Neurol 2001; 58(7):1151-6.

11) Henn V, Young LR. Ernst Mach on the vestibular organ 100 years ago. ORL J Otorhinolaryngol Relat Spec 1975;37(3):138-48.

12) Wiest G, Baloh RW. The pioneering work of Josef Breuer on the vestibular system. Arch Neurol 2002;59(10):1647-53.

13) Dasgupta S, Mandala M, Guneri EA. Alexander crum brown: A forgotten pioneer in vestibular sciences. Otolaryngol Head Neck Surg 2020;163(3):557-9.

14) Tamás LT, Mudry A. Endre Hőgyes (1847-1906), forgotten father of the vestibulo-ocular reflex. Otol Neurotol 2019;40(9):e938-43.

15) Flock A. Structure of the macula utriculi with special reference to directional interplay of sensory responses as revealed by morphological polarization. J Cell Biol 1964;22(2):413-31.

16) Ewald JR. Physiologische Untersuchungen Ueber das Endorgan de Nervus Octavus. Wiesbaden: J.F. Bergmann;1892. p.164-5. German.

17) Kim PS. Anatomy. Vol 2. Seoul: Korea Imperial Jaejungwon;1906.

18) Park HW, Park JH. The first textbook of anatomy in Korea. Korean J Anat 2006;39(6):461-9.

19) Bárány R. Physiologie und pathologie des bogengang-apparates beim menschen: klinische studien. Leipzig: F. Deuticke;1907. p.2634. German.

20) Bárány R. Diagnose yon krankheitserscheinungen im bereiche des otolithenapparates. Acta Oto-Laryngol 1920;2(3):434-7.

21) Hallpike CS, Cairns H. Observations on the pathology of Meniere's syndrome. J Laryngol Otol 1938;53(10):625-55.

22) Kim KS. The history of Meniere's disease: Until the discovery of endolymphatic hydrops (1862-1938). J Korean Bal Soc 2005;4(1): 35-41.

23) Dix MR, Hallpike CS. The pathology symptomatology and diagnosis of certain common disorders of the vestibular system. Proc R Soc Med 1952;45(6):341-54.

24) Carlstrom D, Engstrom H, Hjorth S. Electron microscopic and X-ray diffraction studies of statoconia. Laryngoscope 1953;63(11):1052-7.

25) Carlström D, Engström H. The ultrastructure of statoconia. Acta Otolaryngol 1955;45(1):14-8.

26) Wersall J, Engstrom H, Hjorth S. Fine structure of the guinea-pig macula utriculi; a preliminary report. Acta Otolaryngol Suppl 1954;116:298-303.

27) Wersall J. The minute structure of the crista ampullaris in the guinea pig as revealed by the electron microscope. Acta Otolaryngol 1954; 44(4):359-69.

28) Baloh RW. Harold Schuknecht and pathology of the ear. Otol Neurotol 2001;22(1):113-22.

29) Schuknecht HF. Cupulolithiasis. Arch Otolaryngol 1969;90(6):76578.

30) Schuknecht HF, Ruby RR. Cupulolithiasis. Adv Otorhinolaryngol 1973;20:434-43.

31) Kim YM. Anatomical consideration of vestibular organ. Korean J Otorhinolaryngol-Head Neck Surg 1972;15(3):37-43.

32) Noh KT. Functional tests of the semicircular canal apparatus. Korean J Otorhinolaryngol-Head Neck Surg 1972;15(3):45-58.

33) Seong CS. Spontaneous nystagmus \& induced nystagmus electronystagmography \& OKP (optokinetic pattern) test. Korean J Otorhinolaryngol-Head Neck Surg 1972;15(3):59-63.

34) Hall SF, Ruby RR, McClure JA. The mechanics of benign paroxysmal vertigo. J Otolaryngol 1979;8(2):151-8.

35) Epley JM. New dimensions of benign paroxysmal positional vertigo. Otolaryngol Head Neck Surg (1979) 1980;88(5):599-605.

36) Brandt T, Daroff RB. Physical therapy for benign paroxysmal positional vertigo. Arch Otolaryngol 1980;106(8):484-5.

37) McClure JA. Horizontal canal BPV. J Otolaryngol 1985;14(1):30-5.

38) Semont A, Freyss G, Vitte E. Curing the BPPV with a liberatory maneuver. Adv Otorhinolaryngol 1988;42:290-3.

39) Epley JM. The canalith repositioning procedure: For treatment of benign paroxysmal positional vertigo. Otolaryngol Head Neck Surg 1992;107(3):399-404.

40) Brandt T, Steddin S, Daroff RB. Therapy for benign paroxysmal positioning vertigo, revisited. Neurology 1994;44(5):796-800.

41) Baloh RW, Yue Q, Jacobson KM, Honrubia V. Persistent directionchanging positional nystagmus: Another variant of benign positional nystagmus? Neurology 1995;45(7):1297-301.

42) Lempert T, Tiel-Wilck K. A positional maneuver for treatment of horizontal-canal benign positional vertigo. Laryngoscope 1996; 106(4):476-8.

43) Vannucchi P, Giannoni B, Pagnini P. Treatment of horizontal semicircular canal benign paroxysmal positional vertigo. J Vestib Res 1997;7(1):1-6.

44) Gufoni M, Mastrosimone L, Di Nasso F. Repositioning maneuver in benign paroxysmal vertigo of horizontal semicircular canal. Acta Otorhinolaryngol Ital 1998;18(6):363-7.

45) Choung YH, Shin YR, Kahng H, Park K, Choi SJ. 'Bow and lean test' to determine the affected ear of horizontal canal benign paroxysmal positional vertigo. Laryngoscope 2006;116(10):1776-81. 


\section{정답 및 해설}

답 (5)

해 설 이소골 성형술 후 청력 개선을 위해서는 적절한 길이의 보형물을 삽입해야 한다. 보형물의 길이가 짧은 경우는 청력 개선효 과가 떨어질 수 있으며 보형물의 길이가 길 경우에는 탈출의 위험이 높아지며 등골 다리 골절, 등골 탈구, 등골 족판의 함 몰, 외림프 누공 등이 생길 수 있다. 짧은 보철물을 사용하는 경우 고주파의 소리전달을 감소시키고 길이가 긴 보철물을 사 용하는 경우 과도한 장력으로 고막이 늘어남에 따라 낮은 주파수에서 청력 개선 효과가 떨어진다.

참고 문헌: 대한이비인후과학회. 이비인후과학:이과. 파주: 군자출판사;2018. p.464-70, 507-14.

Flint P, Haughey B, Lund V, Robbins K, Thomas JR, Lesperance M, et al. Cummings otolaryngology head and neck surgery. 7th ed. Philadelphia: Elsevier;2021. p.2192-5, 2207-18. 